[Espaço pedagógico]

\title{
PROPOSTA DE ENSINO REMOTO INTENCIONAL: ALGUNS PASSOS PARA UM RECOMEÇO
}

\author{
Profa. Dra. Rosária Helena Ruiz Nakashimai \\ "Para chegar a lugares onde ainda não estivemos, é preciso \\ passar por caminhos pelos quais ainda não passamos". \\ MAHATMA GHANDI
}

Resumo: A partir de fundamentação teórica (NAKASHIMA; LOBO, 2020), foi elaborada uma proposta inicial para o "ensino remoto intencional" (MOTA FILHO, 2020), para as Licenciaturas. Este planejamento de ensino exige intencionalidades pedagógicas coerentes com a atual situação, apoiadas por recursos digitais, analógicos ou "tecnologias transparentes" (CLARK, 2003), como papel, caneta, sistema de correspondências, em busca de formas diferenciadas de estudos contextualizados.

A versão mais atualizada deste artigo está disponível em

https://osf.io/neztk/download

\section{Como ser coautor (a) deste artigo?}

a) Envie-nos suas observações e responda às seguintes perguntas.

b) Quais discussões você adicionaria a este artigo?

c) Você encontrou algum erro ou argumento inconsistente? Dê uma justificativa detalhada. 


\section{PASSO 1: SENSIBILIDADE E ACOLHIMENTO}

1. Dividir cada período do curso em cinco grupos de estudantes.

2. Cada professor/a, do período, ficará responsável pela comunicação (whatsapp) com um grupo.

3. Pedir para que respondam com palavras-chave ou frases curtas (em itens):

a. Quais são seus sentimentos neste período de pandemia?

b. Há algum objeto artístico (imagem, música, poesia ou desenho que você tenha feito) que expresse suas emoções?

c. O que aprenderam neste período, em qualquer âmbito da vida?

d. O que thes sensibiliza, neste momento de pandemia, em relação à futura profissão como professores/as?

e. Quais as principais dificuldades que você tem em participar de atividades remotas de ensino?

4. Cada professor fará a síntese das respostas, do seu grupo, estabelecendo até 10 temas geradores. Ex.:

a. a natureza e o homem: o ambiente;

b. formas de expropriação: relações de poder...

5. Identificar quem não respondeu por estar sem acesso ao whatsapp.

6. Verificar a possibilidade do Campus enviar uma correspondência para esses/as acadêmicos/as, com as questões impressas e com o contato do professor (e-mail e whatsapp), caso seja possível contactá-lo de outro celular/computador, informando sobre a sua situação atual.

\section{PASSO 2: PLANEJAMENTO CURRICULAR}

7. Em cada período, os respectivos professores deverão identificar um tema gerador em comum. 
8. Dois ou três professores do período podem analisar a relação do tema gerador com sua ementa (componente curricular).

9. Criar um grupo do whatsapp com estes alunos e seus professores.

10. Coletivamente, preparar um material com até 15 tópicos' (indicar as referências), estabelecendo as relações da ementa com o tema gerador. [Podemos pensar na publicação desses materiais...]

11. Compartilhar este material no grupo de whatsapp, com os alunos de seu grupo, para que leiam.

12. Pedir para que cada um escolha um tópico para comentar ou indicar um tópico para cada aluno.

13. Explicar que os alunos não devem se preocupar com "certo e errado". O mais importante é que tentem expressar algo do que entenderam, por texto e/ou áudio.

\section{PASSO 3: AVALIAÇÃO, SÍNTESE E FEEDBACK}

14. Em dupla/trio de docentes, fazer a síntese, em tópicos, do que alunos entenderam.

15. Compartilhar esta síntese, em formato de material, no grupo.

16. Os equívocos apresentados deverão ser revistos, sem expor ninguém, por meio de um material explicativo. Exemplo-> "Revisão de alguns conceitos importantes"

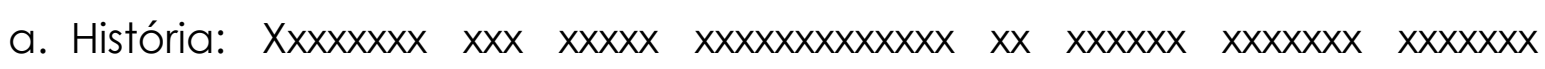
(XXXXXXS, 1955).

\footnotetext{
${ }^{1}$ Exercitar juntos a ideia "Se você consegue explicar algo de modo simples é porque entendeu bem a coisa" (ideia atribuída a Albert Einstein). Ver exemplo no Anexo A.
} 


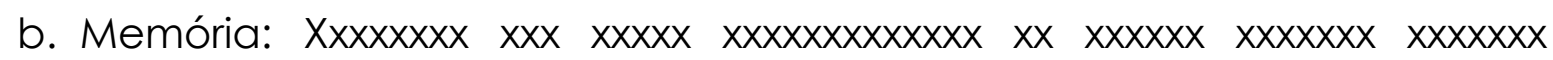
(WWWWW, 1998).

17.Pedir para que cada um relate:

c. O que já sabia sobre essa discussão?

d. O que aprendeu de novo?

e. Quais são as dúvidas que ainda restaram?

f. Como avalia esta experiência de aprendizagem?

18. A partir dos feedbacks, estruturar os próximos passos, visando o aprofundamento de alguns conceitos, conteúdos.

19. Os diferentes tempos para as respostas dos alunos deverão ser respeitados, em uma perspectiva equitativa de condições físicas, intelectuais, emocionais e sociais.

\section{REFERÊNCIAS}

CLARK, Andy. Natural-Born Cyborgs: Minds, technologies and the Future of Human Intelligence. Oxford University Press, 2003.

MOTA FILHO, José. 2020. Seminários Folha "Universidade do Futuro": Impactos na tecnologia. Disponível em:

https://www1.folha.vol.com.br/seminariosfolha/2020/06/folha-realiza-seminario-ofuturo-da-universidade-veja-programacao.shtml. Acesso em 9 jun. 2020.

NAKASHIMA, R. H. R.; LOBO, M. P. "Virada curricular": por uma pedagogia universitária relevante, equitativa e solidária. 2020. Participativa: Ciência Aberta em Revista. Disponível em:

https://revistaparticipativa.wordpress.com/2020/09/03/virada-curricular-por-umapedagogia-universitaria-relevante-equitativa-e-solidaria/. Acesso em 23 set. 2020. 


\section{ANEXO A}

Segue uma forma ${ }^{2}$ de se transformar de um trecho de um texto em item:

\subsection{Conceito}

Existem várias concepções ou acepções a serem tomadas para definir o termo "Constituição". Vejamo-las.

\subsubsection{Sentido Sociológico}

Valendo-se do sentido sociológico, Ferinand Lassalle, em seu livro ¿̇Qué es una Constituición?, defendeu que uma Constituição só seria legítima se representasse o efetivo poder social, refletindo as forças sociais que constituem o poder. Caso isso não ocorresse, ela seria ilegítima, caracterizando-se como uma simples "folha de papel". A Constituição, segundo a conceituação de Lassalle, seria, então, a somatória dos fatores reais do poder dentro de uma sociedade.

(LENZA, Pedro. Direito Constitucional Esquematizado. São Paulo: Método, 2006, p. 43.)

Item:

- No sentido sociológico, Ferdinand Lassalle defende que a Constituição legítima representa o poder social.

i Doutora na área de Didática, Teorias de Ensino e Práticas Escolares, pela Faculdade de Educação da Universidade de São Paulo (USP). Professora Adjunta do Curso de Licenciatura de História da Universidade Federal do Tocantins (UFT), Campus de Araguaína-TO. Docente do Programa de PósGraduação em Estudos de Cultura e Território - PPGCult (UFT). E-mail: rosaria@uft.edu.br 